\title{
A Strategy For Developing A Culture Of Reading Through Folktales For Pre-School Children In Indonesia
}

Hanna Latuputty

Senior Librarian

The British International School

INDONESIA

\begin{abstract}
This paper discusses the relation between the culture of reading and the role of the school library. The paper will look at criteria for selection of suitable books based on the Piaget's theory on the developmental tasks for pre-school children. A limited survey was conducted in some local pre-schools in South Jakarta to get picture of the current situation. Finally, a strategy for using Indonesia's folktales to support the development of a reading culture for pre-school children was formulated.
\end{abstract}

\section{Rationale}

During the $31^{\mathrm{st}}$ Annual Conference of the International Association of School Librarianship (IASL) in Malaysia, a question was raised concerning the condition of school libraries in Indonesia. As a representative of an international school from Indonesia without any involvement with local school libraries beforehand, I found it a hard question to answer. I posted it on to the Indonesian Cyberlibrary Society ( $\mathrm{C}$ C S), a forum whose members deal with documentation, information and library matters. A response from National Library colleague mentioned that pre-schools in Indonesia do NOT have libraries. Table 1 below shows 1999-2000 data on the percentage of schools at each level with and without libraries.

Table I. Data on school libraries condition in Indonesia 1999-2000

\begin{tabular}{|c|r|r|r|r|r|}
\hline Type of schools & Number & $\begin{array}{c}\text { Have } \\
\text { library }\end{array}$ & $\begin{array}{l}\text { \% with } \\
\text { library }\end{array}$ & $\begin{array}{c}\text { Do NOT } \\
\text { have } \\
\text { library }\end{array}$ & $\begin{array}{l}\text { \% with no } \\
\text { library }\end{array}$ \\
\hline Pre-schools & 41,317 & 0 & $0 \%$ & 41,317 & $100 \%$ \\
\hline Elementary Schools & 150,612 & 7,613 & $5.05 \%$ & 142,999 & $94.95 \%$ \\
\hline Junior Schools & 20,866 & 2,901 & $13.98 \%$ & 17,965 & $86.10 \%$ \\
\hline High Schools & 7,900 & 2,104 & $26.90 \%$ & 5,796 & $73.37 \%$ \\
\hline Total schools & $\mathbf{2 2 0 , 6 9 5}$ & $\mathbf{1 2 , 6 1 8}$ & $\mathbf{5 . 7 \%}$ & $\mathbf{2 0 8 , 0 7 7}$ & $\mathbf{9 4 . 3}$ \\
\hline
\end{tabular}

Pre-school years would be a key time to start introducing the habit of reading, although the development of reading for pre-school children needs to be a partnership between parents and their other educators. At school, teachers and librarians may use easy, but meaningful activities in the library, for example borrowing a book; returning a book, listening to a story read by a librarian or teacher, selecting an interesting book and having a good time in the school library. These experiences would develop a positive attitude towards 
libraries in the children and would be carried forward in their education and life-long learning.

On the other hand, Indonesia has many folktales that emanate from the country's many tribal groups. I believe that Indonesian folktales would be a rich source as a part of preschool's library collection. Having reviewed folktales publications in the Indonesian language, it becomes clear that very few are targeted at pre-school children. The books reviewed would not attract their interest, as they only have few pictures in black and white. This type of book would not hold children's attention in reading the stories. I eame across an attractive series of Indonesian Folktales (Citra, 2000a, 2000) published by Elex Media Merchandising, a member of Gramedia Group, e.g., Timun Mas, Malin Kundang, Calon Arang. Si Pitung, and many more. They are full of colour and have good pictures. Unfortunately, the book size is too small $(15 \mathrm{~cm} \times 15 \mathrm{~cm})$ and they have so many words that I assume they are not appropriate for pre-school children. Educators should be aware that preschool years are an important stage at which children can be introduced to books and reading (Melrose, 2002, p.85). Thus, one might ask what are the criteria of books suitable for preschool children to catch their interest in reading?

I was inspired to do more detailed research on the topic of developing reading habit through folktales for pre-school children. I use Bunanta's dissertation (1997) as main resource for Indonesian folktales in preference to her recent books on Indonesian Folktales (2003).

\section{Culture of reading and role of school library in Indonesia}

\section{Culture of reading in Indonesia}

According to The International Education Assessment Test in 1997 (Sutomo, 2003). reading and writing skills for elementary children in Indonesia were taught to $36 \%$ of the total population. The Indonesian Libraries Club conducted another survey, finding that most children participating in the survey like reading. Although parents and teachers encourage children to read. unfortunately it is unlikely to become an enduring habit as there are insufficient books ("Kehiasaan", 2004). Thus, the combination of the lack of books and the very poor condition of ehildren's literacy hampers the improvement of reading culture.

The Ministry of Education and The National Library are holding a National Reading Movement, an event that aims to promote a reading culture. The President of Indonesia, Megawati Sockarnoputri launched it officially on November 12, 2003. Its objectives are to raise the profile of a culture of reading so that it stands alongside oral cultures, to alter reading materials and ensure reading activity becomes a basic need. It also aims to expand and raise awareness of the library"s role in urban and city areas (Departemen Pendikan Nadional, 2003).

However, it remains the responsibility of the government to provide sufficient infrastructures to maximise outcomes from the movement. It would be desirable to set up more libraries, to make books available at an attractive price; and to reduce paper costs to encourage authors to write and publish more books. Last but not least. a broad spectrum of libraries should be given generous support to enable development. The school library sector 
in particular plays a significant part in educational systems in instilling and developing a reading culture.

\section{School libraries in Indonesia}

I received many responses from the I_C_S forum concerning the development and state of school libraries in Indonesia. The following points are a synthesis of the returns:

- School libraries in Indonesia have not developed evenly. As shown in Table I, only $5.7 \%$ of schools have libraries. (Woro Salikin, personal communication).

The condition of these libraries is highly variable from a small, dark and boring rooms to well funded libraries. Further research to find reasons behind these conditions should be conducted. Moreover, school libraries should have a vision to make them dynamic partners in developing the school curriculum, involving teachers, students and school management in the process.

- School libraries need infrastructure to support their development. There was a suggestion that support is needed not only in the technical training in management issues, but also the dynamic cultural process that could increase the library's efficacy was stressed. The training should also cover concepts and materials that reach the root of a child's learning. In addition, this suggestion should be promptly applied as, where the libraries exist, there would be an increasing pressure driving school libraries to serve their community better.

- School libraries need formal. written guidance from government in the context of Education Law.

So, the three points above are indicators of the condition of Indonesian school libraries. They show that school library development is tending to stagnate. The National Library took one step forward in August 2002 when it conceived a formal organisation for school libraries, called Indonesian School Libraries Forum (FPSI) (Prasetyo, 2003). The vision for this organisation is to work together with National Library to move forward in developing a learning society which is information conscious. Its mission is to be a channel for increasing professionalism and to develop school libraries in Indonesia. Its existence should have an important impact in raising the profile of the reading habit among students. However, to work more effectively the roles of the school libraries in Indonesia should be recognised. Thus educators would come to realise how important the school library's roles are in terms of developing a culture of reading. The specific roles of school library in Indonesia are seen as:

- supporting Curriculum Based on Competency (CBC).(Departemen Pendidikan Nasional, 2002) - a prime curriculum guide for schools in Indonesia - a school library should be a place for the enrichment of student's learning. $C B C$ is a set of plans and rules based on competency and students' learning outcomes. A school library should take an active role as a key educational resource in the educational system. Amongst teachers, principals and school committees, a library should be expected to support and enhance results in the learning process.

- maintaining and preserving Indonesian culture and heritage, including Indonesia's folktales. The variety and richness of cultures that used to be a symbol of Indonesia's pride have become vulnerable following consecutive blows including 
the fall of Socharto in 1998, the 'Jakarta Riot' which revealed the mistrust and division between Chinese people and indigenous Indonesian population, civil war in Situbondo, Maluku and Aceh, and many other events. Where there used to be harmony between religions, tribes and cultures, there are now disputes. A recent children's conference (October 2003) focusing on friendship in diversity (Tahloid Nakita, 2003, p6) produced a declaration that Indonesian children should be enabled to borrow books about culture and traditional stories from all over the Indonesian archipelago to promote ethnic harmony through greater understanding of culture delivered through the medium of folktales.

- providing reference facilities to students, teachers, staff, school committee in support of the learning process. Even though the school library would not be able to answer all questions from their clients; the school library should refer clients to other resource centres, persons or companies for the information needed.

- serving the school community in acquiring books and promoting borrowing and returning books.,

- teaching students how to do research. A school library should equip students with research skills as a subsection of library skills, information skills and study skills. Through these skills, school libraries can develop information literacy as a core life skill to their students.

- providing a source of recreation for school communitics. Recreation refreshes one's mind so that creativity is released. Recreational reading should be encouraged as therapy for coping with pressures of coursework. The school library should be a creative and dynamic place that provides services so this role also be seen by school community.

\section{Criteria for selecting books for pre-school children}

The culture of reading improvement should start at home, then, when the children enter their first level of formal education, parents, teachers and librarians work together to implement reading activities to catch and maintain their interest in books and reading. For this purpose, an understanding of children's development would help the educators to supply suitable books.

The endeavour to look more at the development of pre-school children, especially their cognitive development, will be applied in order to identify the criteria for the kind of books that suit their interest. These criteria then would guide the school library to select the appropriate books for pre-school children and thus encourage the development of their culture of reading.

Jean Piaget's theory is applied here to depict pre-school children development. Most of the books or journals about this topic refer in some way to his theory. His description of cognitive developmental stages provides the most sustained and ambitious attempt at studying children's thinking (Fontana, 1995, p.51). The description here will focus on the first two stages that describe children between two and seven years old.

At the pre-operational stage, children's cognitive development is still dominated by physical activities based on their own point of view. Below are some characteristics of preschool children. 


\section{Symbols and signs}

Children between age three and five learn and experience the environment around them using symbols and signs. For example, they use symbols to understand things e.g. they will see a doll stands for a baby; a car toy stands for a real car or, when they role-play as 'Mummy' and 'Daddy', they stand in for a real mum and dad. They also use symbols to assist in memorising other's behaviour. They tend to have self-oriented attitudes, but this does not mean they are selfish. They feel that the world belongs to them and they see it only from their point of view.

Their language skills will develop by using signs. They try to express something by saying the words they known regardless of meaning. Fontana (1995) said:

. . a small child will have a concept of 'bad thing', a concept of 'things I like', a concept of 'things I don't like'. When encountering novel objects or experiences, or faced with problems of any kind, a child attempts to make sense of them by fitting them into the range of concepts already held. If these concepts prove inadequate, s/he may have to modify them in some way, or perhaps try to develop a new concept altogether. (p.52)

So, it is important to develop their language skills by introducing them to books, either by borrowing or by storytelling in a class or a library. By feeding them meaningful concepts, they will have the opportunity to build their knowledge about many things in their experience base.

\section{Imagination}

During these early years, most children will have a rich imagination. Sometimes they have an imaginary friend that they can talk to, get mad at, or a friend to share with. Or they imagine that there is a ghost behind a cupboard or other imaginary things around them. This characteristic is applied as a tool to explore the world and also to understanding their feelings and experiences.

\section{Active information seeking}

Although Piaget's theory has its critics, his perception of the child as an active information seeker is generally accepted. Similarly accepted is his emphasis on the child as the product of interaction between biological maturation and the environment. Children are curious about things in their environment. They are inquisitive and keen to ask about anything that catches their attention. Parents, teachers and librarians should be patient in answering their questions. In answering these questions they may use this opportunity to introduce books as a resource for them to find out the answer themselves.

There are two key indicators of suitable books for pre-school children in terms of coping with both cognitive and physical development. 


\section{Format of material for pre-school children}

Picture book is the most suitable format of books for pre-school children. To synchronise with their way of learning, a picture book brings excitement and interest to the reading experience. Children learn through pictures that express their world, especially if these are offered in colour. The size of picture books also plays an important part. For teachers or librarians who run story telling for their children, a big size is a preferable. As pre-school children are very active, large attractive picture books (e.g. $24 \mathrm{~cm} \times 35 \mathrm{~cm}$ ) eatch their interest and encourage them to sit and read or to sit and hear. Louise (1998, p.15) mentioned four types of picture books: lift-the-flap books, bath books, board books and popup books

\section{Content of material for pre-school children}

The content of both narrative and images should stimulate the imagination, drawing upon the environment around children. The story should cover the multitude of events that happen in their day-to-day life. One thing that should be borne in mind is that the books should concentrate only one aspect of any experience at a time. Children will easily understand only things that appear as a stand alone event. To adjust to their language skills, books should have a word count between 400 and 1000 words (Melrose, 2002, p.89). Folktales are an ideal source to extend their imagination. Stories like legends, myths, origins of gods, humans, and the universe will enrich their fantasy. Bunanta (1997, p.61) found that children have an ability to fantasise in appropriate situations. They enjoy reading folktales because their content is interesting.

\section{Indonesian Folktales for pre-school children}

Indonesia is a country in Southeast Asia that consists of more than 17,500 islands that stretch across more than 5,000 kilometres. Only half of the islands have been named. The five main islands are Sumatra, Java, Kalimantan, Sulawesi and Papua (formerly Irian Jaya). Indonesia has an extremely diverse population. The population of approximately 220 million people belong to about 300 different tribes and speak more than 250 languages.

Storytelling was a common activity among Indonesian people as a way of passing on the folktales. As in other cultures, many parents use folktales to teach their children about morals, education, religion and other life values. Obviously they would like to have their children live in good ways of life. Storytelling can be applied in many ways. Instead of simply telling the stories at bedtime. Bunanta (2003) said that

Traditional storytelling takes place everwhere throughout the archipelago.

Each ethnic group has its own art of storlyelling. These performances will last hours, hegimning in the evening and contimuing until dewn. In some cases a performance mat contimue over several dens. (p/2)

One recent development had seen storytelling activities spread to shopping malls, bookshops, hospitals, urban areas, and are also heard on television or radio. Opportunities to pass on Indonesian folktales have increased as a result.

Many benefits can result from the telling of folktales to children: 
- they can accommodate children's curiosity and ignite their imagination, especially when they introduce fantastic places with extraordinary stories.

- they can be used to show experiences and feelings

- they can be used to introduce other cultures within Indonesia and in doing so, they develop a respect for cultural diversity, and

- according to Bunanta (1997, p.55) folktales will lead children to learn a story that will help them increase their narrative ability and allow them to mature and be ready to understand more complex literature.

Books on Indonesia's folktales for pre-school children appear to have an interesting and educational role in the promotion of a reading habit for pre-school children, but to what extent are they being read and told in pre-schools?

\section{Survey of some Indonesian pre-schools}

In order to get realistic data regarding the use folktales for pre-school children, a survey was undertaken of four local pre-schools near The British International School, in Jakarta. There are many schools that vary from public schools, independent schools, national plus schools and international schools.

Table 2 Respondents' Profile

\begin{tabular}{|l|l|l|l|l|}
\hline & A & B & C & D \\
\hline Type of school & Independent & Independent & Independent & Independent \\
\hline $\begin{array}{l}\text { Total collection } \\
\text { items }\end{array}$ & 8866 & about 2000 & No figures & about 2000 \\
\hline $\begin{array}{l}\text { Library Staff } \\
\text { qualifications }\end{array}$ & $\begin{array}{l}\text { 1 (Bachelor } \\
\text { Degree in } \\
\text { Library } \\
\text { Science) } \\
\text { 1 Diploma in } \\
\text { Economics }\end{array}$ & $\begin{array}{l}\text { I (Bachelor } \\
\text { Degrec in } \\
\text { Library } \\
\text { Science) } \\
4 \text { other staff }\end{array}$ & $\begin{array}{l}\text { I Bachelor } \\
\text { degree in } \\
\text { Education } \\
\text { Administration }\end{array}$ & $\begin{array}{l}\text { 1 Bachelor } \\
\text { Degree in } \\
\text { Education } \\
\text { Administration } \\
\text { 1 High School }\end{array}$ \\
\hline
\end{tabular}

These four schoolswere selected as they were the first four available to participate. All of them are independent schools. I visited three of them, but interviewed the librarian of school B by phone. School A suggested that school B should be included. The seven questions of the interviews are presented below with a summary of responses.

\section{Question 1: Do you have a library?}

All of respondents answered yes. The condition of all these libraries is very cosy. Each was in a classroom-sized area with air conditioning and carpeted floors without tables and chairs. School A has Japanese style tables that enable students to sit on the floor.

The collections include reference and fiction books, video cds and audiocassettes. I observed the similarity of the fiction collections, especially their folktales. All four libraries have a series of Folktales of Indonesia. This series has sixty-five titles of folktales from around the country. The other folktales books are old and long out of print and they looked 
dusty and worn out. Most of these books were paperbacks and only few of them had colour illustrations.

It was a pleasantly surprising to see the condition of these libraries. I did not expect to see library facilities in the schools as the data presented in Table 1 indicate that in 1999 to 2000 no pre-schools had libraries. However, all of these schools are independent, so they are relatively well funded to build libraries with sufficient resources to maintain a collection. Unfortunately, the librarians reported facing difficulties in getting new, good books for their collection. There is a lack of options for selecting good books either in the bookstores or through publishers' catalogues. The availability of children's books should be increased. This may be part of Indonesian School Libraries Forum and Indonesia's publishers' purpose in joining together and improving the existing situation. In the current system, the teachers may suggest some books to buy for the library or they buy books and are reimbursed.

\section{Question.2: Do you have borrowing service for pre-school children?}

Schools A, C and D answered yes. School B answered no, because the librarian does not perceive pre-school children as being responsible enough to look after books.

Both librarians and teachers should be aware that borrowing a book from the library is a service for pre-school children that allows them to enjoy the book, not only in school, but also at home. There might be a chance for them to loose it, but the important thing is they would experience the opportunity of having a book to take home and return. This becomes a part of learning process for them to acknowledge the library's role and at the same time they learn about responsibility. So, it is advisable for the librarian and teachers to develop circulation systems for pre-school children. A consequence is that the librarian should acquire more books for the library's collection.

\section{Question 3: Do you have storytelling service and how often?}

All librarians said that they have this service, even though in practice they shared the task with class teachers. Schools B and C have story time timetabled once a week and schools $A$ and D have story time once a month. The library seems to have little influence over the timetable and thus storytelling remains under-utilised. Storytelling time is a recommended activity to be carried out both by the librarian and the teachers. It would be an advantage for children's development if this activity is timetabled everyday. They can use the existing collection or they can bring book from home and share it at school, just as children at school D do currently.

During their cognitive development, pre-school children should receive as many stimuli as possible. They should obtain as much information as possible about anything to enhance their language skills and build up conceptual knowledge. A key activity to support this is storytelling. The association of pictures and colours of the books in each page can concur with their symbolic way of learning. Words that they hear from librarian or teacher guide pronunciation and give meaning that will develop both their vocabulary and language skills in general.

Library staff and teachers need to work together in planning the storytelling time. Using the library as a base for storytelling is an ideal way to catch children's interest in books and reading. 


\section{Question 4: Have you ever used folk tales in storytelling? Which titles?}

School A said Malin Kundang and Timun Mas, both are part of Folktales of Indonesia (FI) series. School C mentioned Malin Kundang, Lutung Kasarung, Cindelaras and Sangkuriang (all are part of FI series), Hans Andersen collection and stories about animals. Schools B and D can not answer the question as teachers are the story tellers.

Apparently, most of the school libraries are using the folk tale books in their storytelling time. Although they are not using all of the titles in the FI series, teachers and librarians have introduced the stories to children. During the interviews, those at schools $\mathrm{A}$ and $\mathrm{C}$ said that they have to select those stories that are suitable for the children.

\section{Question 5: What are the favourite folk tales for pre-school children?}

Schools A and C said Malin Kundang was the favourite tale for pre-school children. They both use the same version of the take as found in the FI series. School B cannot answer, as the librarian was not involved in the process and School D did not give title.

There are many versions of Malin Kundang. Basically, this is a story about a child who neglected his mother and got a curse from her. This is a good story to teach about respect for parents, to accept them as they are, and also to be a humble person. According to Bunanta (2003),

"Malin Kundang is the most famous story of ungrateful children. The story comes from West Sumatra Province, which is passed from generation to generation all over the country. People in Indonesia believe that parents' blessings and pravers will help children to live safe and happy lives. " (p.53)

\section{children?}

Question 6: Do you find difficulties finding folk tales that suitable pre-school

School A said yes because she hardly found any suitable books for children and the existing books are not colourful. School B answered yes as the librarian found there was a lack of available options. School $\mathrm{C}$ said there were some difficulties as the current collection is limited in titles of this genre. The librarian was a bit concerned that the content of the stories may be too 'adult' for pre-school children. School D answered yes as she too has difficulty in finding stories that suit pre-school children.

\section{Question 7: Do you have comment to make on Indonesia folktales?}

School A commented on the extremely limited availability of this genre. Pre-school children need books that have more illustrations, fewer words, bigger drawings, and a larger format than seen in those currently available. School B also remarked the lack of availability of folk tale books. School B saw a chance for publishers and authors to formulate folk tales for pre-school children, although there was still some concern about selection based on content that suits pre-school children. School $\mathrm{C}$ also commented on the content of the story to be selected for pre-school children. School D gave a suggestion to use multimedia enhancement alongside the book. 


\section{Shortcoming of the survey}

Some other different types of schools should be visited for comparison with the above libraries, such as public schools, so that more of the varied conditions can be seen. The way in which this research was initiated was to an extent limited by the time and resources to access a wider range of institutions.

\section{Conclusion}

Pre-school children are at a perfect age to learn many things from their environment, including reading. This is a crucial time for parents, teachers and librarians to start introduce them to reading and the joy of books. Educators must be aware and understand how this age group develops so that they are able to provide them suitable resources and in doing so nurture their potential talents and abilities. Those schools that have library already need to increase their storytelling service and to develop their collection to suit pre-school children in terms of promoting the library's role in developing a reading culture. Recommendations are that folktale books for pre-school children should have minimum eriteria such as:

- be in a larger size (e.g A4 and A3 size) and full of colours

- have a lot of illustrations

- have between 400 and 1000 words

- include a selection of stories that are suited to pre-school children's cognitive development.

- The strategy is

- to rewrite folktales for pre-school children based upon the criteria above and publish them

- to promote the folktales books for pre-school version and utilise them as a resource during storytelling in the library, at home and more widely generally.

- to encourage the library in pre-schools to have more borrowing time and storytelling time for the children.

\section{References}

Bunanta. Murti. (2003). Indonesian Folktales [retold by]. Westport, ("T: Libraries Unlimited.

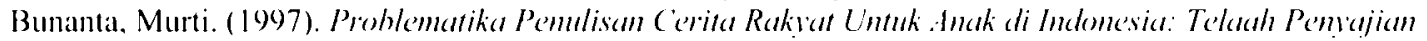

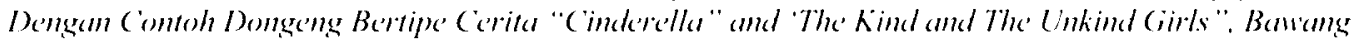
Merah Batang Puth. Depok, Jakarta: Program Pascasarjana, UI.

(itra (2000a). Si Pitumg (C'ritu deri Be'tawi). Jakarta, Indonesia, Elex Media Merchandising.

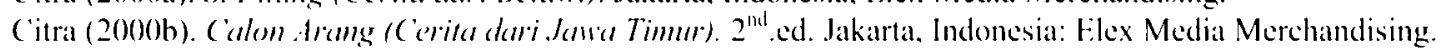

Deklarasi Konferensi Anak-anak Indonesia (2003, I November 2003). Tuhloid Nakita. 239 (V). p.6.

Departemen Pendidikan Nasional. Departemen Dalam Negeri dan Perpustakaan Nasional (2003). Pencanangan (jerakan Membaca Nasional. Retrieved March 15,2004 from

halp: 202.155.38.12 download pde dokumen_ketembagatall 2000311121+1713.pde

Dongeng bukan sekadar pengantar tidur. (2004, January 24). Kompes, p.39.

Departemen Pendidikan Nasional. (2002). Kurikulum berbasis kompetensi. Retrieved February 18.2004 from hutp: wWw puskur.or.id

Fontanil, ID. (1995). Concept formation and cognitive development. In Psycholegy for keschers. pp51-69). Hampshire, UK: Macmillan Press Ltd. 
Kehiasadem membaca dan filosofiny.a. (2003, Oktober - November). Lembar Bagi Rasa, Kluh Perpustakaum Indonesia. 5 (1).

Louise, J. (1998). How to write for children and get published. London: Judy Piatkus.

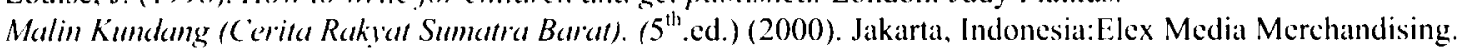
Melrose, A. (2002). Write for children. London: Routledge Falmer.

Prasetyo, Bambang Dwi. (2003). FPSI dan masa depan perpustakacan sekolah Indonesia. Paper di sajikan dalam Diskusi Panel Pemberdayaan perpustakan sekolah dalam pelaksaan kurikulum berbasis kompetensi pada tanggal 28 Agustus di Perpustakaan Nasional.

Sutomo, Sumengen. (2003, Oktober-November). Membangun Bangsa Indonesia 100 tahun Melalui Budaya Baca dan Belajar (suatu pemikiran). In Lembar Bagi Rasa. Kluh Perpustakcan Indonesia. 5 (3).

\section{Author note}

Hanna Latuputty was born in Jakarta, July 2, 1970. She has been working as a school librarian at Secondary Resource Centre, The British International School, Jakarta, Indonesia for many years. She was educated in University of Indonesia, majoring in Library Science. Her concern in developing school libraries in Indonesia has brought her paper to be presented at SLA/IASL Joint Conference, Dublin, Ireland. 